\title{
Antimicrobial Peptides in the Oral Environment: Expression and Function in Health and Disease
}

\author{
Beverly A. Dale and L. Page Fredericks
}

Beverly A. Dale*, Dept. of Oral Biology, Box 357132, University of Washington, Seattle, WA 98195-7132, USA; L. Page Fredericks, Dept. of Oral Biology, Box 357132, University of Washington, Seattle, WA 98195-7132, USA

\begin{abstract}
The oral cavity is a unique environment in which antimicrobial peptides play a key role in maintaining health and may have future therapeutic applications. Present evidence suggests that $\alpha$-defensins, $\beta-$ defensins, LL-37, histatin, and other antimicrobial peptides and proteins have distinct but overlapping roles in maintaining oral health and preventing bacterial, fungal, and viral adherence and infection. The expression of the inducible hBD-2 in normal oral epithelium, in contrast to other epithelia, and the apparent differential signaling in response to commensal and pathogenic organisms, provides new insights into innate immunity in this body site. Commensal bacteria are excellent inducers of hBD2 in oral epithelial cells, suggesting that the commensal bacterial community acts in a manner to benefit the overall innate immune readiness of oral epithelia. This may have major significance for understanding host defense in the complex oral environment.
\end{abstract}

\section{The oral environment}

The oral cavity is a unique environment. Oral mucosa is a critical protective interface between external and internal environments and must serve as a barrier to the myriad microbial species present in this warm, moist environment. The oral cavity is the only area of the body in which hard tissues break through the epithelial surface. The periodontal epithelium surrounding the tooth is specialized to form an attachment and seal around each tooth. This unique function imparts special challenges to the tissue and leads to certain vulnerabilities associated with periodontal disease, especially in view of the continual exposure to the bacterial biofilm (dental plaque) that forms on the tooth surface at the junction of the soft tissue. Thus, this anatomical region is one where there is a significant risk of bacterially induced infection and inflammation.

Antimicrobial peptides are important contributors to maintaining the balance between health and disease in this complex environment. These include several salivary antimicrobial peptides, the $\beta$-defensins expressed in the epithelium, the $\alpha$-defensins expressed in neutrophils, and the cathelicidin, LL-37, expressed in both epithelium and neutrophils. These peptides are part of the host

*For correspondence: bdale@u.washington.edu; L. P. Fredericks, Forsyth Institute 140 The Fenway, Boston, MA 02115 innate immune response in this environment. Epithelia, polymorphonuclear leukocytes (neutrophils), and saliva all contribute to the maintaining the health of the oral cavity in overlapping but independent ways. This review will focus on the human oral cavity and include 1) the expression and function of antimicrobial peptides in the oral cavity in the context of innate immune responses, 2) regulation of $\beta$-defensins which has led to advances in our understanding of oral epithelial innate immunity, and 3) functional efficacy against oral microbes when it is known.

\section{Epithelial antimicrobial peptides}

Historically, the oral epithelium has been considered mainly as a passive covering that becomes damaged and ulcerated in disease. This view has changed dramatically and the epithelial compartment is now seen as providing both a physical barrier to infection and playing an active role in innate host defense (Dale, 2002; Darveau et al., 1997; Ganz, 2003; Tonetti, 1997). Epithelial cells are in constant contact with bacterial products from supra- and sub-gingival biofilms on the tooth surface as well as from bacteria attached to mucosal surfaces. These cells respond to bacteria in an interactive manner; they secrete IL-8 and other chemokines and cytokines to alert various cell types and attract neutrophils. They also produce natural antimicrobial peptides and proteins constitutively and inducibly in response to bacterial exposure. These antimicrobial peptides are part of the innate immune system, a complex set of responses that keeps microbial invaders in check and maintains the microbial ecology of the healthy mucosa (Weinberg et al., 1998). Thus, the epithelium functions to actively respond to the environment, participates in response to infection, in signaling further host responses, and in integrating innate and acquired immune responses.

The first antimicrobial peptide identified in oral epithelium was the $\beta$-defensin, lingual antimicrobial peptide (LAP), described in bovine tongue (Zasloff et al., 1995). We now know that several families of natural antibiotic peptides or proteins are expressed in oral epithelium. These include members of the $\beta$ defensin family of peptides, the protein calprotectin (also known as calgranulin), and the multifunctional peptide, adrenomedullin (Dale and Krisanaprakornkit, 2001; Devine, 2003; Ganz, 2003; Kapas et al., 2001a; Ross and Herzberg, 2001). These antimicrobials have broad specificity with activity against Gram-positive and Gramnegative bacteria (reviewed in Hancock, 1997), as well as against yeast and some viruses (Ganz, 2003; Lehrer and Ganz, 2002; Quinones-Mateu et al., 2003). They complement the antimicrobial factors of saliva, such as the histatins, lysozyme, and salivary immunoglobulins. Both constitutive and inducible antimicrobial peptides are expressed in gingival epithelium, suggesting that they 
have a normal surveillance function as well as a specific role in innate host defense in response to infection. The role of these natural antibiotics is only just beginning to be appreciated, with potential applications for enhanced natural expression or as new therapeutic agents. Their role may be especially important for the oral cavity in which there is constant exposure to microbial challenges (Dale and Krisanaprakornkit, 2001; Weinberg et al., 1998). Further, individual variation in expression may contribute to disease susceptibility. Overall expression of antimicrobial peptides in the oral cavity is summarized in Table 1.

\section{$\beta$-Defensins in oral cells and tissue}

Human $\beta$-defensins (hBDs) are expressed in all human epithelial tissues tested to date including those of the oral cavity (Dale and Krisanaprakornkit, 2001; Lehrer and Ganz, 2002). $\beta$-defensins are expressed in gingiva, tongue, salivary glands, and mucosa (Mathews et al., 1999). They are present in oral inflammatory conditions, oral carcinomas, and some cell lines derived from oral carcinomas (Abiko et al., 1999; Mizukawa et al., 2000). Oral keratinocytes have been a useful model for investigation of the regulation of $\beta$-defensin expression. The human peptide hBD-1 is constitutively expressed while hBD-2 and hBD-3 are upregulated in inflamed skin and other epithelia (Diamond et al., 1991; Harder et al., 1997a; Harder et al., 2001; Krisanaprakornkit et al., 2000; Krisanaprakornkit et al., 1998; Liu et al., 2002; Schonwetter et al., 1995; Singh et al., 1998; Stolzenberg et al., 1997; Valore et al., 1998; Zhao et al., 1996). These and similar peptides in other mammalian species are induced by inflammation and proinflammatory cytokines, and in some cell types, by bacterial lipopolysaccharide (LPS) (Diamond and Bevins, 1994; Diamond et al., 2000; Diamond et al., 1996; Russell et al., 1996). Oral epithelial tissues and oral epithelial cells derived from gingiva express hBD-1, -2, and -3 (Dunsche et al., 2002; Dunsche et al., 2001; Krisanaprakornkit et al., 2000; Krisanaprakornkit et al., 1998). Oral expression of other members of the large $\beta$-defensin family recently identified by Schutte and coworkers is not yet characterized (Schutte et al., 2002).
$\beta$-Defensins in oral tissue. Normal uninflamed gingival tissues express both hBD-1 and hBD-2. Both the constitutive and inducible $\beta$-defensins have been found in essentially all gingival biopsies tested, both healthy uninflamed and inflamed samples (Krisanaprakornkit et al., 2000; Krisanaprakornkit et al., 1998). Thus, normal non-inflamed oral epithelial tissue is activated to express hBD-2, in contrast to normal epidermis, trachea, and gut. This expression of hBD-2 is not accompanied by upregulation of markers of host innate immune response such as IL8. It seems to be part of the normal barrier function of gingival epithelia. The hypothesis is that this exposure represents a useful interaction between the commensal bacteria and the tissue, resulting in enhanced expression of hBD-2 and therefore providing an advantage in subsequent response to other potentially pathogenic organisms. This may be a general paradigm, since it has been shown that Staphylococcus epidermidis, the major commensal skin bacterium, also is an excellent inducer of hBD-2 in epidermal keratinocytes (Chung and Dale, 2004; Dinulos et al., 2003). The role of hBD-1 may be in preventing commensal bacteria from becoming opportunistic pathogens, while hBD-2 and hBD-3 and other inducible antimicrobials may be more effective against pathogens.

$\beta$-Defensins are differentially regulated in oral keratinocytes. HBD-1 is constitutively expressed in oral keratinocytes while hBD-2 is upregulated by bacterial and proinflammatory stimuli (Krisanaprakornkit et al., 2000; Mathews et al., 1999). The unstimulated level of hBD-2 is extremely low and upregulation of mRNA expression occurs rapidly, within 2-4 hr after stimulation with bacterial products or TNF $\alpha$. Stimulants include TNF $\alpha$, IL1 $\beta$, Fusobacterium nucleatum (a commensal oral bacteria, not associated with periodontal disease), and Porphyromonas gingivalis, a periodontal pathogen. Nevertheless, bacterial LPS preparations from $F$. nucleatum, $P$. gingivalis and E.coli are relatively poor inducers of hBD-2 in oral keratincytes (Krisanaprakornkit et al., 2000). This is in contrast to regulation in tracheal epithelial cells in which hBD-2 is upregulated by $E$. coli LPS (Becker et al., 2000; Diamond et al., 2000). HBD-3 is

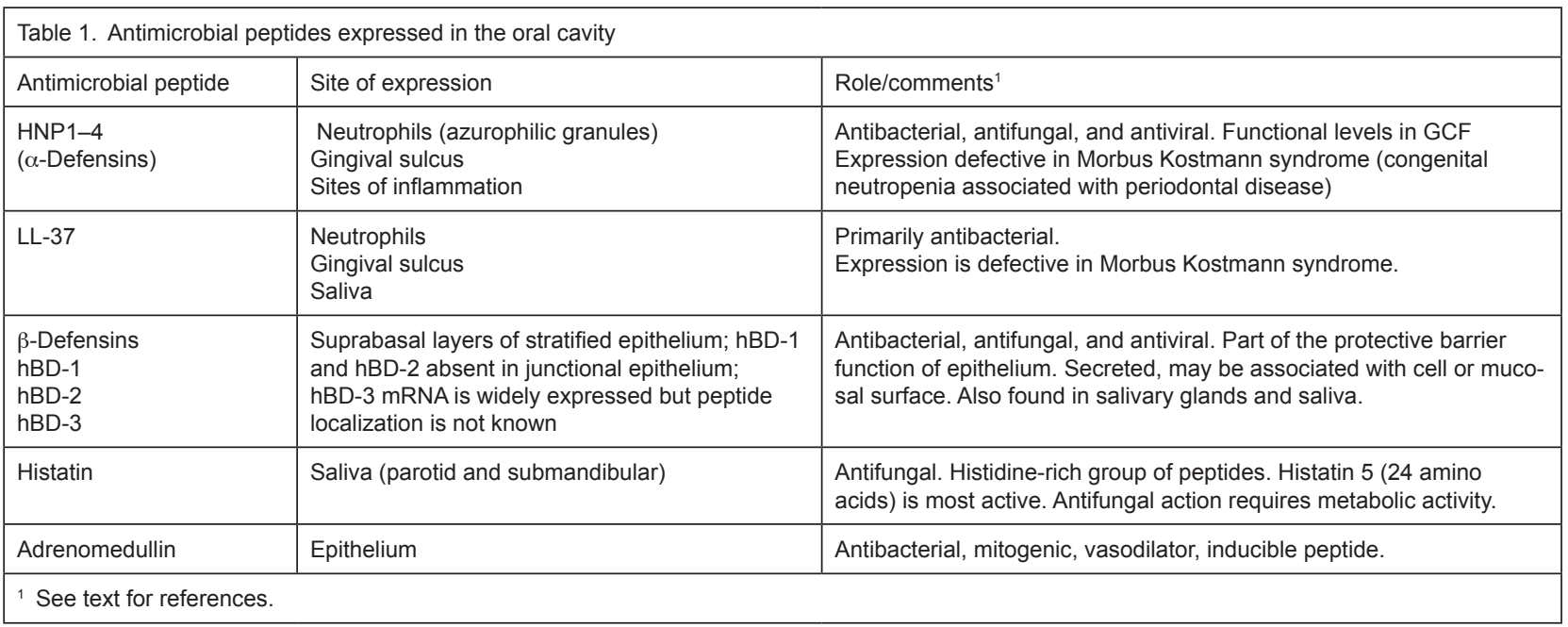


upregulated by interferon- $\gamma$ (Garcia et al., 2001), various bacteria (Harder et al., 2001), and by Actinobacillus actinomycetemcomitans in oral epithelial cells (Feucht et al., 2003).

$\beta$-Defensin expression is associated with differentiation. HBD-1 and hBD-2 mRNA and peptides are expressed as a function of differentiation in cultured oral keratinocytes. In keratinocytes in vitro, the peptides are detected only in cells that are expressing involucrin, an early marker of differentiation (Dale et al., 2001; Dale and Krisanaprakornkit, 2001). In normal gingival tissue mRNAs for both hBD-1 and hBD-2 are most strongly expressed in the spinous layer of the tissue, while the peptides are detected in the upper spinous, granular, and cornified layers. The strongest expression is at the gingival margin, adjacent to the region of plaque formation on the tooth surface and in inflamed sulcular epithelium (Dale et al., 2001). The tissue location is consistent with a role for these peptides in the epithelial antimicrobial barrier. HBD1 and hBD-2 are not detected in junctional epithelium although this region is frequently the site of inflammation. However, the cells of the junctional epithelium are relatively undifferentiated in contrast to other regions of the oral cavity (Schroeder and Listgarten, 1997). The lack of expression in the junctional epithelium, the suprabasal localization in stratified epithelia, and the association with differentiation in vitro, all point to a dependence on normal differentiation for expression of $\beta$-defensins in stratified oral epithelia as well as in the epidermis (Liu et al., 2002).

\section{Epithelial antimicrobials}

Calprotectin. Calprotectin or calgranulin is a heterodimeric calcium- and zinc-binding protein, also referred to as S100A8 and S100A9. It is expressed in neutrophils, monocytes, macrophages, and mucosal keratinocytes and is involved in leukocyte trafficking and arachidonic acid metabolism (Nacken et al., 2003). It is upregulated in inflammatory conditions, including periodontal disease in which it is elevated in the gingival cervicular fluid (Kido et al., 1999). It is constitutively expressed in cells of stratified oral epithelia and in cultured gingival epithelial cells (Ross and Herzberg, 2001) and is highly responsive to stress in epidermis (Marionnet et al., 2003). The mechanism of antimicrobial action of calprotectin appears to be due to competition for zinc, a growth requirement for many microbial species (Brandtzaeg et al., 1995). Calprotectin expression confers protection from bacterial binding and invasion and may contribute to resistance of gingival cells to invasion by Porphyromonas gingivalis, a gram-negative periodontal pathogen (Nisapakultorn et al., 2001).

Adrenomedullin. Adrenomedullin is a multifunctional peptide that was initially characterized for its vasodilatory effects and subsequently has been recognized to have antibacterial function against both Gram positive and Gram negative bacteria from the oral cavity, skin, respiratory tract and gut (Allaker and Kapas, 2003). It does not display antifungal activity. It is constitutively expressed and secreted by oral epithelial cells; expression is also increased in response to live oral bacteria, IL1, and TNF $\alpha$ (Kapas et al., 2001a; Kapas et al., 2001b). Adrenomedullin consists of 52 amino acids with one intramolecular disulfide bond. The precursor is encoded by the ADM gene which maps to human chromosome 11. Although there are some functional parallels to the $\beta$-defensins, the adrenomedullin gene and protein structure differ from that of the $\beta$-defensins. Adrenomedullin has some homology with calcitonin gene-related peptide (Kitamura et al., 1993) and binds to the calcitonin receptor-like receptor (McLatchie et al., 1998) and is thought to have hormone-like functions in the control of circulation. Mice lacking expression of adrenomedullin die in mid-gestation due to cardiovascular abnormalities (Caron and Smithies, 2001).

\section{Epithelial and neutrophil antimicrobial peptides function together in gingiva}

Neutrophil antimicrobial peptides work together with the epithelium to provide a barrier to microbial colonization in the oral cavity, particularly in the region adjacent to the tooth surface. The junctional epithelium which forms the attachment of the soft tissue to the tooth surface is less differentiated and more permeable than the sulcular or oral surface epithelium. Neutrophils migrate through the junctional epithelium in response to a gradient of IL8 expressed in the junctional and sulcular epithelia (Tonetti et al., 1998). The importance of neutrophils in oral health is readily seen by the severity of problems in individuals with defects in neutrophil chemotaxis or function. Such defects are associated with severe periodontal disease occurring at a young age (see below).

\section{LL-37 and $\alpha$-defensins}

The cathelicidin, LL-37, is expressed in epithelial cells especially following inflammatory stimulation, and both the protein and mRNA have been detected in human tongue and buccal mucosa (Frohm Nilsson et al., 1999) and saliva (Murakami et al., 2002). However, LL-37 detected in gingival epithelium by immunohistochemisty appeared to be the product of neutrophil migration through the tissue rather than the epithelial cells per se (Dale et al., 2001). In addition, the neutrophil $\alpha$-defensins, HNP-1-3, are readily detected in the junctional epithelium (Dale et al., 2001). They can be detected in quantities consistent with their antimicrobial function in the gingival crevicular fluid that lies between the epithelium and the tooth surface (McKay et al., 1999).

Localized expression of antimicrobial peptides in gingiva The $\alpha$ - and $\beta$-defensins and LL-37 are localized in different sites in the gingiva, suggesting that they may serve different roles in the several ecological niches of the periodontium. The $\beta$-defensin peptides, hBD- 1 and hBD-2 are localized in the differentiated layers of the gingival epithelium in a pattern of expression consistent with function as a microbial barrier (Dale et al., 2001). Their expression is particularly strong at the gingival margin where the tissue can be expected to be in nearly continuous contact with supragingival plaque. While $\beta$ defensins are poorly expressed in the undifferentiated cells of junctional epithelium, the $\alpha$-defensins and LL-37 
are present in high amounts in neutrophils that migrate through the junctional epithelium to the gingival sulcus. Thus, junctional epithelium is protected by $\alpha$-defensins and LL-37 released from neutrophils, whereas the differentiated stratified epithelia are protected by $\beta$ defensins (Dale et al., 2001; McKay et al., 1999). Taken together in the context of the oral cavity, the observations on tissue and gingival fluid suggest that the gingiva is protected by $\alpha-$ and $\beta$-defensins, LL-37, and salivary antimicrobial peptides as summarized in Fig. 1. This is quite analogous to the findings in intestine in which the crypts are protected by $\alpha$-defensins and the epithelia of intestinal villae express $\beta$-defensins (Bevins et al., 1999). Both $\alpha$ - and $\beta$-defensins, as well as LL-37, signal other innate and acquired immune responses (see below, reviewed in Lehrer and Ganz, 2002) in addition to their antimicrobial properties.

\section{The expression and regulation of antimicrobial peptides indicates heightened innate immune responses in oral epithelia}

\section{$H B D-2$ is expressed in both normal and inflamed oral epithelia}

In contrast to most other epithelia, in which hBD-2 is expressed only in the presence of infection or inflammation (including skin, trachea, gut epithelium), this peptide is expressed in normal uninflamed gingival tissue (Dale et al., 2001). Present evidence suggests that the high level

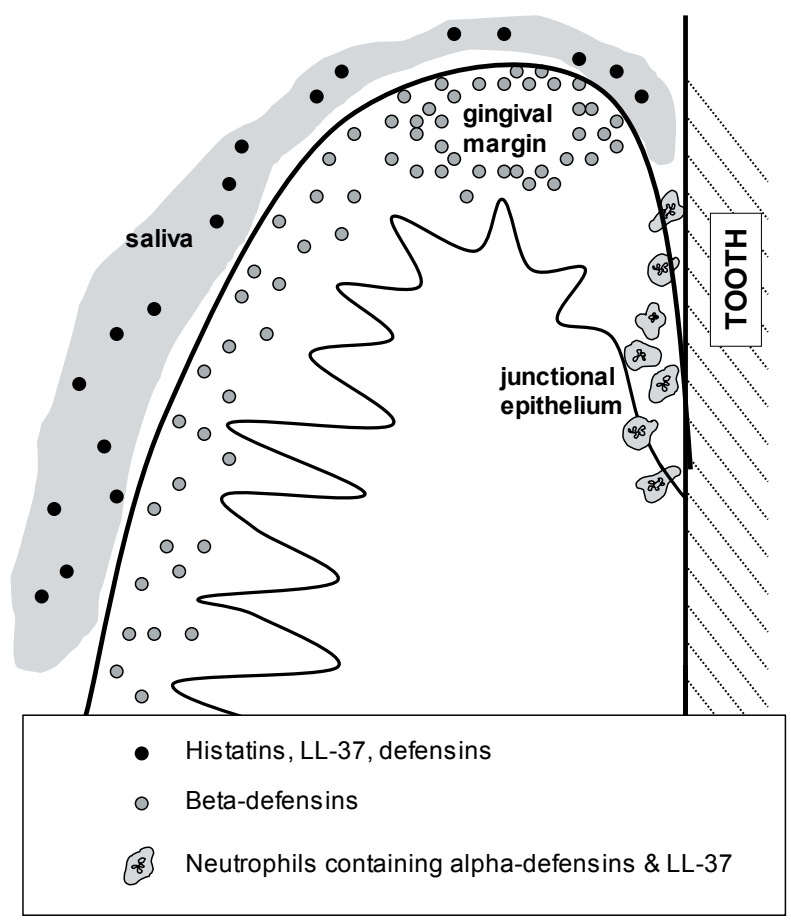

Fig. 1 Localized expression of antimicrobial peptides in gingiva. Diagrammatic view of a cross-section of the gingiva illustrating the oral aspect of the tissue, the gingival margin at the crest of the gum tissue, and the junctional epithelium attaching to the tooth surface. The sulcular epithelium is adjacent to the space (sulcus) between the tissue and the tooth. Neutrophils, containing $\alpha$-defensins and LL-37, migrate through the junctional epithelium into the gingival sulcus. $\beta$-Defensins are expressed in the gingival epithelium. The tissue is bathed in saliva containing histatins, LL-37 and $\alpha-$ and $\beta$-defensins. of hBD-2 expression is due to the exposure of the tissue to commensal, non-pathogenic bacteria (Krisanaprakornkit et al., 2000) and that the innate immune responses of normal oral epithelia are at a heightened state of readiness. This has been most clearly demonstrated in studies of $\beta$ defensin expression in oral epithelial cells in vitro. Normal oral gingival epithelial cells do not express hBD-2 in cell culture unless stimulated. Commensal and pathogenic bacteria, proinflammatory cytokines and phorbol ester, a general cell activator, are all effective stimulants. Cell wall preparations of the commensal organism, F. nucleatum, are particularly effective in up-regulating hBD-2 mRNA expression (Krisanaprakornkit et al., 2000).

\section{Signaling pathways for $h B D-2$ in oral epithelial cells}

HBD-2 up-regulation in response to oral commensal bacteria does not seem to utilize the NF-кB intracellular signaling cascade typically associated with recognition of bacterial products, but instead utilizes the JNK and p38 mitogen activated protein kinase (MAPK) pathways that are associated with cytokine and stress responses (Krisanaprakornkit et al., 2002). Intracellular calcium signaling is also involved (Krisanaprakornkit et al., 2003). Utilization of this signaling pattern has now been extended to show that commensal organisms from both oral and skin sites do not utilize the $\mathrm{NF}-\kappa \mathrm{B}$ pathway for hBD-2 up-regulation, in contrast to pathogens which use an NF-kB pathway (Chung and Dale, 2004). This differs from results in other tissues, for example,

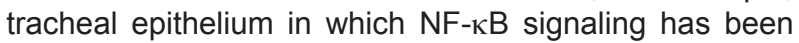
demonstrated (Diamond et al., 2000). This signaling pathway may represent an adaptation to the normal population of both Gram positive and Gram negative bacteria within the oral cavity. Similarly, colon epithelial cells upregulate hBD-2 expression poorly in response to LPS (O'Neil et al., 1999). The findings in oral epithelial cells are consistent with the hypothesis that oral epithelia are capable of distinguishing commensal and pathogenic organisms, that immune response signaling mechanisms in the presence of commensal bacteria differ from those in response to pathogens, and that the expression of hBD2 is part of this scenario. Because commensal bacteria are excellent inducers of hBD-2 in oral epithelial cells, these findings suggest that the oral commensal bacterial community acts in a manner to benefit the overall innate immune readiness of oral epithelia. This may have major significance for understanding host defense in the complex oral environment. The receptors, molecular mechanisms and signaling pathways responsible for the distinction are not yet fully understood. Further, interpretation of various experimental approaches may be complicated by cross-talk between various receptor-mediated signaling pathways.

\section{Epithelial receptors for $h B D-2$ regulation}

Mammalian cells sense the presence of bacteria via Pattern Recognition Receptors, such as the Toll-like receptor or TLR family (Medzhitov, 2001). Lipoteichoic acid and peptidoglycans of Gram positive organisms and LPS of Gram negative bacteria signal via TLR2 and TLR4, respectively, activating $\mathrm{NF}-\kappa \mathrm{B}$ transcription factors and the JNK pathways that mediate up-regulation of multiple 
innate and inflammatory responses. TLR2 and -4 are expressed on oral epithelial cells and up-regulated with interferon gamma stimulation (Uehara et al., 2002b). The LPS binding factor, CD14, a cofactor in the association of bacterial LPS to TLR4, is poorly expressed on epithelial cells but is present in soluble form in plasma. HBD-2 regulation in tracheal epithelial cells occurs via CD14, and NF-кB-mediated signaling (Becker et al., 2000; Diamond et al., 2000), and/or via TLR2-mediated signaling (Hertz et al., 2003). However, there is not yet convincing evidence that this pathway is involved in hBD-2 regulation in oral epithelial cells.

A second family of recently described receptors is the proteinase-activated receptors or PARs (Coughlin, 2000; Mackie et al., 2002). PARs act as sensors of possible danger, have a role in inflammation, and may also have a central role in the recognition of, and response to, bacteria within the oral cavity (Mackie et al., 2002), including regulation of the inducible $\beta$-defensins. Because the three major Gram-negative pathogens associated with periodontal disease, $P$. gingivalis, Bacteroides forsythus (recently renamed Tannerella forsythensis) and Treponema denticola (Socransky et al., 1998) each have proteases as part of their virulence mechanisms (Curtis et al., 2001; Fenno et al., 2001; Saito et al., 1997); these receptors may aid in differentially stimulating epithelial cell responses to pathogenic vs. commensal oral bacteria. PARs are implicated in platelet activation and response to injury via thrombin and trypsin (Lourbakos et al., 2001; Uehara et al., 2002a). PARs are seven-transmembrane domain G-protein coupled receptors. PAR activation involves proteolytic cleavage of the extracellular domain, resulting in a new amino-terminus that acts as a tethered ligand that binds to one of the extracellular loops of the receptor (Coughlin and Camerer, 2003; Mackie et al., 2002). PAR-1, -3 , and -4 are activated by thrombin; PAR2 is activated by various trypsin-like enzymes, including mast cell tryptase, neutrophil proteinase 3 , as well as $P$. gingivalis proteinases (Lourbakos et al., 1998). These receptors can also be activated by peptide agonists that mimic the proteolytically produced amino-terminus. A PAR-2 peptide agonist up-regulated hBD-2 mRNA in oral epithelial cells and $P$. gingivalis mutants lacking proteinase fail to upregulate hBD-2, suggesting a role for PAR-2 in regulation of hBD-2 expression (Chung et al., 2004).

\section{Other functions of antimicrobial peptides in the oral cavity}

There is a growing recognition that the functions of chemokines and antimicrobial peptides overlap (Cole et al., 2001; Durr and Peschel, 2002). Epithelial cells signal Langerhans cells, the antigen presenting cells within epithelia, via cytokines, chemokines, and $\beta$-defensins, to connect innate immune responses with acquired immunity (Banchereau and Steinman, 1998; Yang et al., 1999). HBD-1 and hBD-2 act as chemoattractants for dendritic cells and T-cells. They also act as ligands for the receptor CCR6, a G-protein coupled receptor located in immature dendritic cells. Activation of the receptor results in dendritic cell maturation (Yang et al., 1999). Interestingly, the natural ligand for CCR6 is the chemokine CCL20 which has been shown to have structural similarity to hBD-2 (Hoover et al.,
2002) and has antimicrobial activity (Starner et al., 2003). HBD-2 has also been reported as a ligand for TLR4 in dendritic cells (Biragyn et al., 2002), however, this finding is somewhat controversial and could be due to the ability of cationic hBD-2 to efficiently bind and act as a carrier for LPS delivery to the TLR4 receptor. HBD-2 also has effects on mast cells resulting in histamine release and intracellular $\mathrm{Ca}^{++}$mobilization in a $\mathrm{G}$ protein-phopholipase $\mathrm{C}$ dependent manner (Niyonsaba et al., 2001).

The antimicrobial peptide LL-37 is a chemoattractant for neutrophil, monocytes and T-cells (Chertov et al., 1996; Yang et al., 2000). It also stimulates mast cells and alters macrophage gene expression to upregulate chemokines and their receptors resulting in greater responsiveness to the environment (Scott et al., 2002; Scott et al., 2000). HBD-2 also up-regulates gene expression for numerous cytokine and chemokine receptors in oral epithelial cells in a manner reminiscent of LL-37 (Yin and Dale, manuscript in preparation). Thus, hBD-2 enhances epithelial cell responses and alters gene expression in oral epithelial cells as well as mast cells and dendritic cells.

$\alpha$-Defensins also have multiple functions as was recently reviewed (Yang et al., 2002). They selectively attract naïve CD4+ T-cells and immature dendritic cells via a G-protein coupled receptor (Yang et al., 2000). $\alpha-$ Defensins also stimulate mast cell degranulation (Befus et al., 1999), regulate complement activation (Prohaszka et al., 1997; van den Berg et al., 1998), and enhance macrophage phagocytosis (Ichinose et al., 1996).

Together these observations support the view that antimicrobial peptides promote adaptive immunity against microorganisms by recruiting both naïve T-cells, memory T-cells and antigen-presenting dendritic cells to regions of infection and stimulate repair and clean-up of infected sites via effects on mast cells and macrophages. In the oral cavity, this is an important ongoing process, particularly in the region of the gingival sulcus.

\section{Salivary antimicrobial peptides}

Antimicrobial components of the saliva (excluding salivary $\lg \mathrm{A}$ ) are generally referred to as the non-immune factors, but can be considered as part of the innate immune system of gene encoded factors that aid in protection against oral microbial colonization and infection (reviewed by Nieuw Amerongen and Veerman, 2002). These include a number of proteins such as salivary peroxidase, lysozyme, lactoferrin, cystatins, SLPI, agglutinin and mucins as well as peptides of the histatin family. In addition, the cathelicidin, LL-37, and $\alpha$ - and $\beta$-defensins are expressed and secreted by salivary glands and/or ducts.

\section{$\alpha$ - and $\beta$-Defensins}

$\beta$-Defensins have been demonstrated in salivary duct cells, but not acinar cells by immunohistochemical means (Sahasrabudhe et al., 2000) and in salivary glands and saliva by protein and RT-PCR analyses (Bonass et al., 1999; Mathews et al., 1999; Sahasrabudhe et al., 2000). HBD-1 mRNA has been identified in all major and minor salivary gland samples, while hBD-2 mRNA has been identified in a portion of samples, possibly associated with inflammation (Bonass et al., 1999). The secretion of $\beta$-defensins in saliva as well as their secretion from 
epithelial cells (Diamond et al., 2001) may contribute to the protection of oral mucosal surfaces. Levels of $\beta$-defensins in saliva have not been quantified. The $\alpha-$ defensins, HNP1-3, have also been detected in saliva and are elevated in patients with oral inflammation (Mizukawa et al., 1999). Levels of HNP1-3 vary in healthy individuals ranging from undetectable to $\sim 12 \mu \mathrm{g} / \mathrm{ml}$ (Goebel et al., 2000; Mizukawa et al., 1999). The presence of $\alpha-$ defensins in saliva is most likely derived from neutrophils and is a reflection of gingival or mucosal inflammation and loose or exfoliating teeth.

\section{LL-37}

Expression of the mouse cathelicidin CRAMP was detected in salivary acinar cells of submandibular and palatine minor glands (mRNA and protein), ducts cells (protein) and mucosa in both embryonic and adult mice. In the human, LL37 was detected in saliva (Murakami et al., 2002). The results suggest localized expression of different antimicrobial peptides in salivary glands and ducts, similar to that of the gingiva (see above).

\section{Histatins}

Histatins are a family of at least 12 histidine-rich, cationic peptides synthesized by parotid and submandibular salivary duct cells and present in saliva (reviewed by Devine, 2002). Multiple histatins are generated from proteolytic cleavage of histatin 1 (38 amino acids) and 3 (32 amino acids). Histatins 1, 3, and 5 comprise approx. $85 \%$ of the total histatin protein in saliva. Histatins exhibit antifungal properties in vitro with histatin 5 having the most potent fungicidal activity (Oppenheim et al., 1988). The HTN genes map to chromosome $4 q 13$, and the histatins are expressed only in salivary glands (vanderSpek et al., 1989), in contrast to the more general expression pattern of other antimicrobial peptides.

Histatins and oral candida. Saliva plays a critical role in regulating Candida adhesion to mucosal surfaces (Ueta et al., 2000). A high frequency of oral candidiasis occurs in patients with reduced salivary flow, such as in patients with Sjögren's syndrome and histatins appear to be a main player in control of oral Candida (Jainkittivong et al., 1998). The fungicidal action of histatins requires active mitochondria (Helmerhorst et al., 1999a). $\alpha$-defensins and histatins share some aspects of their antifungal action which is associated with ATP transport and reaction with purinergic-like cell surface receptors (Edgerton et al., $2000)$. The relationship of histatins and $\alpha$-and $\beta$-defensins with oral Candida is not clear, but these peptides may work synergistically.

\section{Altered antimicrobial peptide expression in the oral cavity}

The innate immune system is essential in preventing infection, and the relationship of antimicrobial peptides and an individual's susceptibility to infection is an important area of investigation. A current approach to identification of protein function is to identify the physiologic consequences in null mice lacking expression of the gene under investigation. This approach has led to advances in the understanding of the role of LL-37 in systemic and skin infection by $S$. aureus (Nizet et al., 2001). However, because there are numerous defensins, it is not possible to unequivocally prove their importance by knock out technology in a mouse model system. An alternate approach was used by Wilson and coworkers (Wilson et al., 1999) in which they disrupted the gene for matrilysin, the enzyme required for activation of Paneth cell $\alpha$-defensins in the intestine. A second approach is to take advantage of experiments of nature - via genetics and the occurrence of genetic disorders.

\section{Neutrophil defects and defects in expression of $\alpha-$} defensins and $L L-37$

It has been known for many years that periodontal disease in prepubertal children is associated with defects in neutrophil function (Page et al., 1985). With a general neutrophil defect, for example in the chemotactic response, or in cyclic neutropenia, periodontal disease may occur in association with increased occurrence of otitis media and other repeated infections (reviewed by Hart and Kornman, 2000). Recently a genetic form of periodontal disease (PD) in young people, Morbus Kostmann syndrome, was shown to have a deficiency in the $\alpha$-defensins, HNP1-3, and a near absence of LL37 (Putsep et al., 2002). This led to the suggestion that LL-37 may be particularly important in its effects vs. the Gram-negative, Actinobacillus actinomycetemcomitans, an organism associated with rapidly progressive PD especially in young people.

Another early onset inherited form of PD is the Papillon-Lefevre syndrome in which the genetic defect is in the gene for cathepsin C, a lysosomal protease (Hart et al., 1999; Toomes et al., 1999). Periodontal disease and palmar/plantar hyperkeratosis occur in this disorder but without an associated high frequency of other types of infections. Apparently a specific effect of cathepsin $C$ is important in each of these body sites, however, the key substrate(s) for cathepsin $C$ in neutrophils and epidermis is(are) not known. To date, altered processing of antimicrobial peptides has not been examined in this disorder, but is among the possible candidate substrates.

\section{Genetics and the defensins}

HBD-1 polymorphism and oral candida carriage. Occurrence of genetic polymorphisms offers another means to ask questions about the role of antimicrobial peptides in oral health and disease. Multiple single nucleotide polymorphisms (SNPs) have been identified in the DEFB1 and DEFB2 (now renamed DEFB4) genes, encoding hBD-1 and hBD-2, respectively (Dork and Stuhrmann, 1998; Jurevic et al., 2002; Vatta et al., 2000). Such SNPs may alter the expression or function of defensins and could lead to altered susceptibility to infection. The SNPs, especially those that had a reasonably high frequency, occur mainly in promoter and untranslated regions of these genes. These SNPS could potentially alter the amount of the peptide expressed, but not the peptide itself. Individuals with Type 1 diabetes are susceptible to oral Candida infection and have marginal immunosuppression, therefore, these minor differences in $\beta$-defensin genes may have significant effects in this 
population. The diabetic population had nearly 3-fold higher average oral Candida carriage than a non-diabetic group. However, in both populations, a SNP in DEFB1 (-44 $C$ to $G$ ) was found to be associated with protection from oral Candida carriage. In other words, people who had the SNP had very low levels of oral Candida. The difference in relative risk for high Candida carriage was 25 $(p<0.01)$ for the diabetic population and 8.5 for the nondiabetic group (Jurevic et al., 2003). The most obvious interpretation of this finding is that this SNP alters hBD1 expression. Initial results using a molecular approach to address this possibility strongly suggest that the SNP results in increased hBD-1 protein expression, and this may explain the basis of the apparent protection from oral Candida carriage. Alternatively, the SNP may be linked to a genetic change in another functional gene in this chromosomal region. Nevertheless, the results suggest that individuals who are immunosuppressed, and thus more susceptible to opportunistic infections, may have greater reliance on innate immune defenses than healthy individuals who have multiple ways to fight infection.

Defensin gene duplications. Hollox and co-workers (Hollox et al., 2003) recently demonstrated variable copy number indicative of gene duplication within the $\beta$-defensin cluster on Chr. 8p23. They showed that individuals can have from 2 to 12 copies of the region of DEFB4, DEF103, and DEFB104 encoding hBD-2, hBD3 , and hBD-4, respectively, per diploid genome. This repeat region does not include the genes encoding the $\alpha$-defensins or hBD-1. Inheritance of genes encoding the $\alpha$-defensins can also vary, but less extensively (Mars et al., 1995). The frequency of low vs. high copy number and the effect on peptide expression is not yet known, but may be an important factor in oral antimicrobial function.

\section{Efficacy of antimicrobial peptides in the oral cavity}

The oral cavity provides an inviting warm, moist environment conducive to colonization by many types of microorganisms. Thus the normal oral flora is extremely complex, requiring multiple types of defenses in order to prevent infection. These defenses include antimicrobial peptides with different, but overlapping, ranges of microorganisms against which they are effective. The oral cavity also provides an environment that allows optimal effectiveness of these peptides. Activity of most of the oral antimicrobial peptides is inhibited by ions/salt at physiologic levels (Goldman et al., 1997; Nagaoka et al., 2000; Turner et al., 1998); however, in the oral environment, they function at the surface away from high salt concentrations and interfering substances in the blood. Table 2 provides data from numerous sources on the activity of these peptides against various, mainly pathogenic, oral bacteria and fungi (see table for references for this section). The antimicrobial function of these peptides has been obtained through a myriad of methods, making comparisons and interpretations difficult. It should also be recognized that very few methods test for bactericidal (lethal) as opposed to bacteriostatic activity.

\section{Peptide activity}

LL-37. LL-37 is a cathelicidin with the conserved proregion which keeps it inactive until proteases cleave this portion after the protein is secreted (Zanetti et al., 2000). Against oral microbes, LL-37 has the greatest activity against $A$. actinomycetemcomitans and Capnocytophaga spp. A. actinomycetemcomitans is an important pathogen associated with rapidly progressive forms of periodontal disease which often affect younger individuals. Capnocytophaga spp. have been implicated in juvenile gingivitis and periodontitis and can cause sepsis in immunocompromised patients (Gomez-Garces et al., 1994).

$\alpha$-Defensins. $\alpha$-Defensins are relatively ineffective against most of the oral microbes tested, with the exceptions of Capnocytophaga ochracea and C. albicans. However, synergy between HNP-1 and LL-37 has been demonstrated against E. coli and Staphylococcus aureus even at physiological salt concentrations (150 mM) (Nagaoka et al., 2000). HNP-1 requires target microbes to be metabolically active (Edgerton, et al., 2000). HNP1-3 also show inhibitory effects on HIV infectivity.

$\beta$-Defensins. $\beta$-Defensins show both anti-fungal and antibacterial action. HBD-3 is consistently more active against both bacteria and fungi, with hBD-2 next and hBD-1 last in activity. The study by Joly and coworkers compared the effectiveness of hBD-2 and hBD-3 against oral microorganisms. HBD-2 and hBD-3 show considerable variability against multiple strains of the same species, but overall, aerobes are more susceptible than anaerobes. These peptides also show strain-specific activity toward various Candida spp. (Joly et al., 2004). Interestingly, Wu and coworkers showed that hBD-3 activity against $E$. coli was unaffected by disulfide bonding which was previously thought to be critical to antimicrobial function (Wu et al., 2003). Along with the $\alpha$-defensins, hBD-2 and -3 inhibit HIV replication. HBD-2 has anti-fungal activity against $C$. albicans and $C$. tropicalis, while hBD-3 is active against other Candida spp. tested.

Histatins. Histatins are primarily anti-Candida agents. They have little effect on oral bacteria or on the fungus Aspergillus fumigatus. Histatin-5 is the most effective histatin and is active against $C$. albicans as well as other Candida spp. Histatins have activity in the concentration range found in saliva. Johnson, Yeh and Dodds (Johnson et al., 2000) measured histatin concentrations in saliva at $31 \mu \mathrm{g} / \mathrm{ml}$ in parotid secretions and $62 \mu \mathrm{g} / \mathrm{ml}$ in submandibular/submaxillary secretions. They also found that these concentrations decline by one half and one third, respectively, between the ages of $45-75$. Synergistic effects have been demonstrated between histatin- 5 and amphotericin B against Candida spp., including an amphotericin B-resistant strain, Cryptococcus neoformans and $A$. fumigatus (van't Hof et al., 2000). 


\begin{tabular}{|c|c|c|c|c|c|c|c|c|}
\hline Organism & hBD1 & hBD2 & hBD3 & HNP-1 & HNP-2/-3 & LL-37 & Histatin & Adrenomedulin \\
\hline Escherichia coli $1,3,4,5,11,20,21,23$ & $\begin{array}{l}40 \\
(\geq 3) \\
5(0.5)\end{array}$ & $\begin{array}{l}10(1) \\
0.6(0.5)\end{array}$ & $\begin{array}{l}5(\geq 3) \\
0.1(0.5)\end{array}$ & $50(\geq 3)$ & & $\begin{array}{l}1.0 \\
10(\geq 3)\end{array}$ & & 0.4 \\
\hline Streptococcus mutans s $^{1,6,8,10,12}$ & & $4.1-7.8^{b}$ & $\begin{array}{l}2.6-5^{b} \\
2(\geq 3)\end{array}$ & & & & NS & 12.5 \\
\hline S. sanguis s $^{3,6,8,10}$ & & $8-25^{b}$ & $\begin{array}{l}7.6-21.3^{b} \\
16(\geq 3)\end{array}$ & & & $>100(\geq 3)$ & NS & \\
\hline S. salvarius ${ }^{6}$ & & & & & & & NS & \\
\hline S. sobrinus ${ }^{10}$ & & & $16(\geq 3)$ & & & & & \\
\hline Actinomyces naes/undii $1,6,8$ & & $8-14^{b}$ & $4.1-7.2^{\mathrm{b}}$ & & & & NS & 12.5 \\
\hline $\begin{array}{l}\text { Fusobacterium nuclea- } \\
\text { tum }\end{array}$ & & $\begin{array}{l}6.3- \\
>250^{b}\end{array}$ & $4.5->250^{b}$ & $>500$ & & $>100(\geq 3)$ & NS & \\
\hline Veillonella parvula ${ }^{6}$ & & & & & & & $(0.3)$ & \\
\hline Prevotella intermedia ${ }^{6}$ & & & & & & & NS & \\
\hline $\begin{array}{l}\text { Porphyromonas gingiva- } \\
\text { lis }^{1,3,8,10,12}\end{array}$ & & $\begin{array}{l}34.6- \\
>250^{\mathrm{b}}\end{array}$ & $\begin{array}{l}5.7->250^{b} \\
100(\geq 3)\end{array}$ & & & $>100(\geq 3)$ & & $7.75 \times 10^{-4}$ \\
\hline $\begin{array}{l}\text { Actinobacillus actinomy- } \\
\text { cetemcomitans }^{3,8,10,12,13,15}\end{array}$ & & $>250$ & $\begin{array}{l}9.6->250^{b} \\
2.5(\geq 3)\end{array}$ & NS (1) & NS (1) & $\begin{array}{l}10(2) ; \\
>100(\geq 3)\end{array}$ & & \\
\hline Lactobacillus acidophilus $^{10}$ & & & $8(\geq 3)$ & & & & & \\
\hline $\begin{array}{l}\text { Capnocytophaga sputi- } \\
\text { gena }{ }^{13,19}\end{array}$ & & & & $\begin{array}{l}200(1) ; \\
500(2)\end{array}$ & $500(1)$ & $7.5(2)$ & & \\
\hline C. gingivalis ${ }^{13,19}$ & & & & $200(1)$ & $500(1)$ & $9.1(2)$ & & \\
\hline C. ochracea ${ }^{13,19}$ & & & & $\begin{array}{l}10(1) ; \\
500(2)\end{array}$ & $10(1)$ & $11.0(2)$ & & \\
\hline Candida albicans ${ }^{1,2,3,7,8,9,17,18,20}$ & $>500$ & $\begin{array}{l}25(1) \\
125 \\
4.6-59^{b}\end{array}$ & $25 ; 2.8-7.1^{\mathrm{b}}$ & $\begin{array}{l}>250(\geq 3) ; \\
96 \%(52 \\
\mu \mathrm{g} / \mathrm{ml}) \text { LOV }\end{array}$ & & $\begin{array}{l}>250(\geq 3) \\
>100(\geq 3)\end{array}$ & $\begin{array}{l}97 \%(14 \mathrm{ug} / \mathrm{ml}) \text { LOV; } \\
>500[24 \mathrm{hr}] \\
2.4(0.5) ; \\
50 \mu \mathrm{M}(1.5) ; \\
100 \mu \mathrm{M}(2)\end{array}$ & NS \\
\hline resist. C. albicans ${ }^{9,22}$ & & 125 & 25 & & & & $125[24 \mathrm{hr}]$ & \\
\hline C. glabrata $^{7,8,9,15,22}$ & & $\begin{array}{l}23- \\
>250^{\mathrm{b}} \\
>1000\end{array}$ & $\begin{array}{l}34->250 \\
50\end{array}$ & & & & $\begin{array}{l}62.5[24 \mathrm{hr}] \\
29(0.5) ; \\
42-87 \% \text { LOV }^{3}\end{array}$ & \\
\hline resist. C. glabrata ${ }^{7,9}$ & & $>1000$ & 200 & & & & $1.0(0.5)$ & \\
\hline C. kruse $^{3,7,8,9,15,22}$ & & $\begin{array}{l}12- \\
>250^{\mathrm{b}} \\
>1000\end{array}$ & $\begin{array}{l}2-13.7^{\mathrm{b}} \\
200\end{array}$ & & & $>100(\geq 3)$ & $\begin{array}{l}500[24 \mathrm{hr}] \\
1.2(0.5) ; \\
80-95 \% \text { LOVa }^{2}\end{array}$ & \\
\hline C. neoformans ${ }^{7,22}$ & & & & & & & $\begin{array}{l}31.3[24 \mathrm{hr}] \\
0.7(0.5)\end{array}$ & \\
\hline C. pseudotropicalis ${ }^{7}$ & & & & & & & $1.0(0.5)$ & \\
\hline C. parapsilosis ${ }^{7,8,9,15}$ & & $\begin{array}{l}9.3- \\
17.8^{\mathrm{b}} \\
>1000\end{array}$ & $\begin{array}{l}1.4-12.4^{b} \\
50-100\end{array}$ & & & & $2.0^{\mathrm{e}} ; 72-98 \% \mathrm{LOV}^{\mathrm{a}}$ & \\
\hline C. tropicalis ${ }^{3,8,9,15}$ & $>500$ & $\begin{array}{l}3.9- \\
13.1^{\mathrm{b}} \\
125\end{array}$ & $\begin{array}{l}3.3-14.4^{\mathrm{b}} \\
6.25\end{array}$ & & & $>100(\geq 3)$ & $90-98 \%$ LOV $^{a}$ & \\
\hline C. guilleirmondii' ${ }^{15}$ & & & & & & & $90-98 \%$ LOV$^{a}$ & \\
\hline Aspergillus fumigatus ${ }^{22}$ & & & & & & & $>500[24 \mathrm{hr}]$ & \\
\hline HIV $^{15,16,24}$ & NO & YES & YES & YES & YES & & & \\
\hline
\end{tabular}




\begin{tabular}{|c|c|c|}
\hline \multirow[t]{2}{*}{ Key } & \multicolumn{2}{|l|}{ References } \\
\hline & ${ }^{1}$ Allaker \& Kapas, 2003 & ${ }^{13}$ Miyasaki et al., 1990 \\
\hline \multirow[t]{2}{*}{$(\#)=\# \log$ reduction } & ${ }^{2}$ Edgerton et al., 2000 & ${ }^{14}$ Miyasaki \& Lehrer, 1998 \\
\hline & ${ }^{3}$ Guthmiller et al., 2001 & ${ }^{15}$ Nikawa et al., 2001 \\
\hline \multirow[t]{2}{*}[24\mathrm{hr}]{$=$ read at $24 \mathrm{hr}$} & ${ }^{4}$ Harder et al., 2001 & ${ }^{16}$ Quinones-Mateu et al., 2003 \\
\hline & ${ }^{5}$ Harder et al., 1997 & ${ }^{17}$ Raj et al., 1990 \\
\hline \multirow[t]{2}{*}{ LOV $=$ loss of viability } & ${ }^{6}$ Helmerhorst et al., 1999a & ${ }^{18}$ Schröder \& Harder, 1999 \\
\hline & ${ }^{7}$ Helmerhorst et al., 1999b & ${ }^{19}$ Tanaka, Miyasaki \& Lehrer, 2000 \\
\hline \multirow[t]{2}{*}{ NS $=$ no significant activity } & ${ }^{8}$ Joly et al., 2004 & ${ }^{20}$ Turner et al., 1998 \\
\hline & ${ }^{9}$ Jurevic, 2004 & ${ }^{21}$ Valore et al., 1998 \\
\hline \multirow[t]{2}{*}{${ }^{\text {a }}$ range due to different strains $(50 \mu \mathrm{M})$} & ${ }^{10}$ Maisetta et al., 2003 & ${ }^{22}$ Van't Hof et al., 2000 \\
\hline & ${ }^{11}$ Mandal \& Nagaraj, 2002 & ${ }^{23} \mathrm{Wu}$ et al., 2003 \\
\hline${ }^{\mathrm{b}} \mathrm{MIC}$ range due to strain differences & ${ }^{12}$ Mineshiba et al., 2003 & ${ }^{24}$ Zang et al., 2002 \\
\hline
\end{tabular}

Antimicrobial peptides as therapeutic agents in the oral cavity

Antimicrobial peptides are under investigation for control of oral infections. One such drug is Iseganan, an analog of protegrin-1, a porcine cathelicidin, which has broad spectrum bactericidal activity. Iseganan has recently completed Phase III clinical trials for prevention of ulcerative oral mucositis. It showed encouraging results in reducing the occurrence of oral mucositis and associated clinical problems such as mouth pain, throat pain and difficulty swallowing (Giles et al., 2003). A second investigational peptide is the antifungal, histatin-5. The yeast Candida is a commensal organism on skin and mucosal surfaces but is a growing problem in causing opportunistic infections. Frequency of mucosal and invasive fungal infections has increased in association with increased numbers of immunocompromised patients due to HIV, chemotherapy, and the use of immunosuppressive drugs. In addition, there has been an increase in Candida strains that are resistant to the main therapeutic drugs in current use. This has led to an increased interest in new antifungals, primarily antifungal peptides. Histatin- 5 and several variants are under active investigation for this purpose since their mechanism of action differs from the main antifungal drugs in current use and they are effective against azole-resistant Candida strains (Situ and Bobek, 2000; Tsai and Bobek, 1998).

\section{Conclusions}

The oral cavity is a unique environment in which antimicrobial peptides play a key role in maintaining health. Present evidence suggests that $\alpha$-defensins, $\beta$-defensins, LL-37, histatin, and other antimicrobial peptides and proteins have distinct but overlapping roles in maintaining oral health. The expression of the inducible hBD-2 in normal oral epithelium, and the apparent differential signaling in response to commensal and pathogenic organisms, provides new insights into innate immunity in this body site. Commensal bacteria are excellent inducers of hBD2 in oral epithelial cells, suggesting that the commensal bacterial community acts in a manner to benefit the overall innate immune readiness of oral epithelia. This may have major significance for understanding host defense in the complex oral environment.

\section{Future trends}

Future studies will emphasize approaches to learn more about the role of antimicrobial peptides in oral health and susceptibility to disease and infection. Because periodontal disease is largely a situation in which the inflammatory process has gone awry, it is critical to understand the role of innate immunity in the recognition of, response to, and effectiveness against oral microbes. This includes more detailed information about both $\alpha$ - and $\beta$-defensins, LL37 , and other oral antimicrobial peptides and proteins. These peptides very likely have specific functions in keeping the level of commensal bacteria in check as well as being effective against pathogens. The involvement of antimicrobial peptides in other mucosal disorders is also important to understand. In oral squamous cell carcinoma and lichen planus, $\beta$-defensin expression may reveal clues on disease progression and prognosis. Recent evidence of the involvement of $\beta$-defensins in the defense against HIV infection and transmission in the oral environment is fascinating (Quinones-Mateu et al., 2003). There is much more to learn about this effect and how it may be useful therapeutically. Further, studies of expression and function of the newly described members of the $\beta$-defensin family (Schutte et al., 2002) may provide critical new pieces of information relating to oral health.

The initial genetic studies suggesting a protective role of an hBD-1 SNP need extension and confirmation. This finding opens a whole new area of investigation. Does the hBD-1 SNP affect Candida carriage directly via hBD-1 or indirectly via a linked gene? Can this SNP be used as part of a diagnostic susceptibility profile in situations in which Candida infection could become life threatening, such as transplant recipients? Are defensin SNPs correlated with other oral infections? Because defensins are secreted and may function synergistically with salivary antimicrobials they may protect against dental caries, or conversely contribute to genetic susceptibility to dental decay. Similar questions can be asked of the role of LL-37 in oral health and disease. Genetic investigations could be extended to include molecular mechanisms and defects in processing 
of antimicrobial peptides in neutrophils, such as in Morbus Kostmann syndrome and possibly in Papillon-Lefevre syndrome in view of the profound effects of neutrophil antimicrobials on periodontal health.

Another major area of future study is the regulation by and functional efficacy against oral commensal vs. pathogenic organisms. Present evidence suggests that innate immune responses of oral epithelia are primed by commensal bacteria and this occurs via pathways other than those utilized in response to pathogens. This ability of epithelial cells to distinguish commensal and pathogens may represent a general phenomonen since epithelia from different body sites co-exist with different populations of commensal bacteria. Study of the regulation of $\beta$-defensins is a window opening our understanding of this important aspect of innate immunity of oral epithelia as well as epithelia in other body sites. It will also be important to understand the molecular mechanism by which the defensins and LL-37 exert their multiple functions in promoting wound healing and linking innate immunity to acquired immunity.

Finally, the development of new peptide antimicrobial agents for therapeutic use in the oral environment is an important area for future investigation and testing. Peptide antimicrobial agents may augment the innate defenses of individuals at high risk for oral infection because of compromised immune status.

\section{Acknowledgments}

Support for the work of this laboratory on the role of $\beta$-defensins in the oral cavity is from USPHS NIDCR Grants DE P60 013061 and R01 DE 13573 (to B.A.D.). Dr. Fredericks is supported by NIDCR T32 DE07023. We thank Dr. W. O. Chung, and Ms. Janet Kimball for discussions and critical reading of the manuscript.

Added note: Activity of antimicrobial peptides against some addition oral bacterial species and strains was recently reported by Ouhara et al. (2005) J. Antimicro. Chemother. Doi:10.1093/jac/dki103.

\section{References}

Abiko, Y., Mitamura, J., Nishimura, M., Muramatsu, T., Inoue, T., Shimono, M., and Kaku, T. (1999). Pattern of expression of beta-defensins in oral squamous cell carcinoma. Cancer Lett. 143, 37-43.

Allaker, R. P., and Kapas, S. (2003). Adrenomedullin and mucosal defence: interaction between host and microorganism. Regul. Pept. 112, 147-152.

Banchereau, J., and Steinman, R. M. (1998). Dendritic cells and the control of immunity. Nature 392, 245252.

Becker, M. N., Diamond, G., Verghese, M. W., and Randell, S. H. (2000). CD14-dependent lipopolysaccharideinduced beta-defensin-2 expression in human tracheobronchial epithelium. J. Biol. Chem. 275, 29731-29736.

Befus, A. D., Mowat, C., Gilchrist, M., Hu, J., Solomon, S., and Bateman, A. (1999). Neutrophil defensins induce histamine secretion from mast cells: mechanisms of action. J. Immunol. 163, 947-953.
Bevins, C. L., Martin-Porter, E., and Ganz, T. (1999). Defensins and innate host defence of the gastrointestinal tract. Gut 45, 911-915.

Biragyn, A., Ruffini, P. A., Leifer, C. A., Klyushnenkova, E., Shakhov, A., Chertov, O., Shirakawa, A. K., Farber, J. M., Segal, D. M., Oppenheim, J. J., and Kwak, L. W. (2002). Toll-like receptor 4-dependent activation of dendritic cells by beta-defensin 2 . Science 298, 10251029.

Bonass, W. A., High, A. S., Owen, P. J., and Devine, D. A. (1999). Expression of beta-defensin genes by human salivary glands. Oral Microbiol. Immunol. 14, 371-374.

Brandtzaeg, P., Gabrielsen, T. O., Dale, I., Muller, F., Steinbakk, M., and Fagerhol, M. K. (1995). The leucocyte protein L1 (calprotectin): a putative nonspecific defence factor at epithelial surfaces. Adv. Exp. Med. Biol. 371A, 201-206.

Caron, K. M., and Smithies, O. (2001). Extreme hydrops fetalis and cardiovascular abnormalities in mice lacking a functional Adrenomedullin gene. Proc. Natl. Acad. Sci. USA 98, 615-619.

Chertov, O., Michiel, D. F., Xu, L., Wang, J. M., Tani, K., Murphy, W. J., Longo, D. L., Taub, D. D., and Oppenheim, J. J. (1996). Identification of defensin-1, defensin-2, and CAP37/azurocidin as T- cell chemoattractant proteins released from interleukin-8-stimulated neutrophils. J. Biol. Chem. 271, 2935-2940.

Chung, W. O., and Dale, B. A. (2004). Innate immune response of oral and foreskin keratinocytes: utilization of different signaling pathways by various bacterial species. Infect. Immun. 72, 352-358.

Chung, W. O., Hansen, S. R., Rao, D., and Dale, B. A. (2004). Protease-activated receptor signaling increases epithelial antimicrobial peptide expression. J. Immunol. 173, 1565-1570.

Cole, A. M., Ganz, T., Liese, A. M., Burdick, M. D., Liu, L., and Strieter, R. M. (2001). Cutting edge: IFNinducible ELR- CXC chemokines display defensin-like antimicrobial activity. J. Immunol. 167, 623-627.

Coughlin, S. R. (2000). Thrombin signalling and proteaseactivated receptors. Nature 407, 258-264.

Coughlin, S. R., and Camerer, E. (2003). PARticipation in inflammation. J. Clin. Invest. 111, 25-27.

Curtis, M. A., Aduse-Opoku, J., and Rangarajan, M. (2001). Cysteine proteases of Porphyromonas gingivalis. Crit. Rev. Oral Biol. Med. 12, 192-216.

Dale, B. A. (2002). Periodontal epithelium: a newly recognized role in health and disease. Periodontology 2000 30, 70-78.

Dale, B. A., Kimball, J. R., Krisanaprakornkit, S., Roberts, F., Robinovitch, M., O'Neal, R., Valore, E. V., Ganz, T., Anderson, G. M., and Weinberg, A. (2001). Localized antimicrobial peptide expression in human gingiva. J. Periodontal Res. 36, 285-294.

Dale, B. A., and Krisanaprakornkit, S. (2001). Defensin antimicrobial peptides in the oral cavity. J. Oral Pathol. Med. 30, 321-327.

Darveau, R. P., Tanner, A., and Page, R. C. (1997). The microbial challenge in periodontitis. Periodontology $200014,12-32$. 
Devine, D. A. (2003). Antimicrobial peptides in defence of the oral and respiratory tracts. Mol. Immunol. 40, 431-443.

Diamond, D. L., Kimball, J. R., Krisanaprakornkit, S., Ganz, T., and Dale, B. A. (2001). Detection of betadefensins secreted by human oral epithelial cells. J. Immunol. Methods 256, 65-76.

Diamond, G., and Bevins, C. L. (1994). Endotoxin upregulates expression of an antimicrobial peptide gene in mammalian airway epithelial cells. Chest 105, 51S-52S.

Diamond, G., Kaiser, V., Rhodes, J., Russell, J. P., and Bevins, C. L. (2000). Transcriptional regulation of betadefensin gene expression in tracheal epithelial cells. Infect. Immun. 68, 113-119.

Diamond, G., Russell, J. P., and Bevins, C. L. (1996). Inducible expression of an antibiotic peptide gene in lipopolysaccharide-challenged tracheal epithelial cells. Proc. Natl. Acad. Sci. USA 93, 5156-5160.

Diamond, G., Zasloff, M., Eck, H., Brasseur, M., Maloy, W. L., and Bevins, C. L. (1991). Tracheal antimicrobial peptide, a cysteine rich peptide from mammalian tracheal mucosa: peptide isolation and cloning of a cDNA. Proc. Natl. Acad. Sci. USA 88, 3952-3956.

Dinulos, J. G., Mentele, L., Fredericks, L. P., Dale, B. A., and Darmstadt, G. L. (2003). Keratinocyte expression of human $\beta$-defensin-2 following bacterial infection: role in cutaneous host defense. Clin. Diag. Lab. Immunol. 10, 161-166.

Dork, T., and Stuhrmann, M. (1998). Polymorphisms of the human beta defensin 1 gene. Mol. Cell Probes 12, 171-173.

Dunsche, A., Acil, Y., Dommisch, H., Siebert, R., Schroder, J. M., and Jepsen, S. (2002). The novel human betadefensin-3 is widely expressed in oral tissues. Eur J. Oral Sci. 110, 121-124.

Dunsche, A., Acil, Y., Siebert, R., Harder, J., Schroder, J. M., and Jepsen, S. (2001). Expression profile of human defensins and antimicrobial proteins in oral tissues. J. Oral Pathol. Med. 30, 154-158.

Durr, M., and Peschel, A. (2002). Chemokines meet defensins: the merging concepts of chemoattractants and antimicrobial peptides in host defense. Infect. Immun. 70, 6515-6517.

Edgerton, M., Koshlukova, S. E., Araujo, M. W., Patel, R. C., Dong, J., and Bruenn, J. A. (2000). Salivary histatin 5 and human neutrophil defensin 1 kill Candida albicans via shared pathways. Antimicrob. Agents Chemother. 44, 3310-3316.

Fenno, J. C., Lee, S. Y., Bayer, C. H., and Ning, Y. (2001). The opdB locus encodes the trypsin-like peptidase activity of Treponema denticola. Infect. Immun. 69, 6193-6200.

Frohm Nilsson, M., Sandstedt, B., Sorensen, O., Weber, G., Borregaard, N., and Stahle-Backdahl, M. (1999). The human cationic antimicrobial protein (hCAP18), a peptide antibiotic, is widely expressed in human squamous epithelia and colocalizes with interleukin-6. Infect. Immun. 67, 2561-2566.

Ganz, T. (2003). Defensins: antimicrobial peptides of innate immunity. Nat. Rev. Immunol. 3, 710-720.
Garcia, J. R., Jaumann, F., Schulz, S., Krause, A., Rodriguez-Jimenez, J., Forssmann, U., Adermann, K., Kluver, E., Vogelmeier, C., Becker, D., et al. (2001). Identification of a novel, multifunctional beta-defensin (human beta- defensin 3) with specific antimicrobial activity. Its interaction with plasma membranes of Xenopus oocytes and the induction of macrophage chemoattraction. Cell Tissue Res. 306, 257-264.

Giles, F. J., Miller, C. B., Hurd, D. D., Wingard, J. R., Fleming, T. R., Sonis, S. T., Bradford, W. Z., Pulliam, J. G., Anaissie, E. J., Beveridge, R. A., et al. (2003). A phase III, randomized, double-blind, placebo-controlled, multinational trial of iseganan for the prevention of oral mucositis in patients receiving stomatotoxic chemotherapy (PROMPT-CT trial). Leuk. Lymphoma 44, 1165-1172.

Goebel, C., Mackay, L. G., Vickers, E. R., and Mather, L. E. (2000). Determination of defensin HNP-1, HNP-2, and HNP-3 in human saliva by using LC/MS. Peptides 21, 757-765.

Goldman, M. J., Anderson, G. M., Stolzenberg, E. D., Kari, U. P., Zasloff, M., and Wilson, J. M. (1997). Human beta defensin 1 is a salt sensitive antibiotic in lung that is inactivated in cystic fibrosis. Cell $88,553-560$.

Gomez-Garces, J. L., Alos, J. I., Sanchez, J., and Cogollos, R. (1994). Bacteremia by multidrug-resistant Capnocytophaga sputigena. J. Clin. Microbiol. 32, 1067-1069.

Guthmiller, J. M., Vargas, K. G., Srikantha, R., Schomberg, L. L., Weistroffer, P. L., McCray, P. B., Jr., and Tack, B. F. (2001). Susceptibilities of oral bacteria and yeast to mammalian cathelicidins. Antimicrob. Agents Chemother. 45, 3216-3219.

Hancock, R. E. W. (1997). Peptide antibiotics. Lancet 349, 418-422.

Harder, J., Bartels, J., Christophers, E., and Schroder, J. M. (1997a). A peptide antibiotic from human skin. Nature 387, 861.

Harder, J., Bartels, J., Christophers, E., and Schroder, J. M. (2001). Isolation and characterization of human betadefensin-3, a novel human inducible peptide antibiotic. J. Biol. Chem. 276, 5707-5713.

Hart, T. C., Hart, P. S., Bowden, D. W., Michalec, M. D., Callison, S. A., Walker, S. J., Zhang, Y., and Firatli, E. (1999). Mutations of the cathepsin C gene are responsible for Papillon-Lefevre syndrome. J. Med. Genet. 36, 881-887.

Hart, T. C., and Kornman, K. S. (2000). Genetic factors in the pathogenesis of periodontitis. Periodontology 14 , 202-215.

Helmerhorst, E. J., Breeuwer, P., van't Hof, W., WalgreenWeterings, E., Oomen, L. C., Veerman, E. C., Amerongen, A. V., and Abee, T. (1999a). The cellular target of histatin 5 on Candida albicans is the energized mitochondrion. J. Biol. Chem. 274, 7286-7291.

Helmerhorst, E. J., Hodgson, R., van 't Hof, W., Veerman, E. C., Allison, C., and Nieuw Amerongen, A. V. (1999b). The effects of histatin-derived basic antimicrobial peptides on oral biofilms. J. Dent. Res. 78, 12451250.

Helmerhorst, E. J., Reijnders, I. M., van't Hof, W., SimoonsSmit, I., Veerman, E. C., and Amerongen, A. V. (1999c). 
Amphotericin B- and fluconazole-resistant Candida spp., Aspergillus fumigatus, and other newly emerging pathogenic fungi are susceptible to basic antifungal peptides. Antimicrob. Agents Chemother. 43, 702-704.

Hertz, C. J., Wu, Q., Porter, E. M., Zhang, Y. J., Weismuller, K. H., Godowski, P. J., Ganz, T., Randell, S. H., and Modlin, R. L. (2003). Activation of toll-like receptor 2 on human tracheobronchial epithelial cells induces the antimicrobial peptide human beta defensin-2. J. Immunol. 171, 6820-6826.

Hollox, E. J., Armour, J. A., and Barber, J. C. (2003). Extensive normal copy number variation of a betadefensin antimicrobial-gene cluster. Am. J. Hum. Genet. 73, 591-600.

Hoover, D. M., Boulegue, C., Yang, D., Oppenheim, J. J., Tucker, K., Lu, W., and Lubkowski, J. (2002). The structure of human macrophage inflammatory protein-3alpha/CCL20. Linking antimicrobial and CC chemokine receptor-6-binding activities with human beta-defensins. J. Biol. Chem. 277, 37647-37654.

Ichinose, M., Asai, M., Imai, K., and Sawada, M. (1996). Enhancement of phagocytosis by corticostatin । (CSI) in cultured mouse peritoneal macrophages. Immunopharmacology 35, 103-109.

Jainkittivong, A., Johnson, D. A., and Yeh, C. K. (1998). The relationship between salivary histatin levels and oral yeast carriage. Oral Microbiol. Immunol. 13, 181187.

Johnson, D. A., Yeh, C. K., and Dodds, M. W. (2000). Effect of donor age on the concentrations of histatins in human parotid and submandibular/sublingual saliva. Arch. Oral Biol. 45, 731-740.

Joly, S., Maze, D., McCray, P.B. Jr., Guthmiller, J.M. (2004). Human $\beta$-defensin 2 and 3 demonstrate strainselective activity against oral microorganisms. J. Clin. Microbiol. 42, 1024-1029.

Jurevic, R. J., Bai, M., Chadwick, R. B., White, T. C., and Dale, B. A. (2003). Single nucleotide polymorphisms (SNPs) in human $\beta$-defensin-1: High throughput SNP assays and association with Candida carriage in type 1 diabetics and nondiabetic controls. J. Clin. Microbiol. 41, 90-96.

Jurevic, R. J., Chrisman, P., Mancl, L., Livingston, R., and Dale, B. A. (2002). Single nucleotide polymorphisms and haplotype analysis in $\beta$-defensin genes in different ethnic populations. Genet. Test. 6, 261-269.

Kapas, S., Bansal, A., Bhargava, V., Maher, R., Malli, D., Hagi-Pavli, E., and Allaker, R. P. (2001a). Adrenomedullin expression in pathogen-challenged oral epithelial cells. Peptides 22, 1485-1489.

Kapas, S., Tenchini, M. L., and Farthing, P. M. (2001b). Regulation of adrenomedullin secretion in cultured human skin and oral keratinocytes. J. Invest. Dermatol. 117, 353-359.

Kido, J., Nakamura, T., Kido, R., Ohishi, K., Yamauchi, N., Kataoka, M., and Nagata, T. (1999). Calprotectin in gingival crevicular fluid correlates with clinical and biochemical markers of periodontal disease. J. Clin. Periodontol. 26, 653-657.

Kitamura, K., Sakata, J., Kangawa, K., Kojima, M., Matsuo, H., and Eto, T. (1993). Cloning and characterization of
cDNA encoding a precursor for human adrenomedullin. Biochem. Biophys. Res. Comm. 194, 720-725.

Krisanaprakornkit, K., Kimball, J. R., Weinberg, A., Darveau, R. P., Bainbridge, B. W., and Dale, B. A. (2000). Inducible expression of human $\beta$-defensin-2 (hBD-2) by Fusobacterium nucleatumin oral epithelial cells: Multiple signaling pathways and the role of commensal bacteria in innate immunity and the epithelial barrier. Infect. Immun. 68, 2907-2915.

Krisanaprakornkit, S., Jotikasthira, D., and Dale, B. A. (2003). Intracellular calcium in signaling human $\beta$ defensin-2 expression in oral epithelial cells. J. Dent. Res. 82, 877-882.

Krisanaprakornkit, S., Kimball, J. R., and Dale, B. A. (2002). Regulation of human beta-defensin-2 in gingival epithelial cells: the involvement of mitogen-activated protein kinase pathways, but not the NF-kappaB transcription factor family. J. Immunol. 168, 316-324.

Krisanaprakornkit, S., Weinberg, A., Perez, C. N., and Dale, B. A. (1998). Expression of the peptide antibiotic human beta defensin 1 in cultured gingival epithelial cells and gingival tissue. Infect. Immun. 66, 42224228.

Lehrer, R. I., and Ganz, T. (2002). Defensins of vertebrate animals. Curr. Opin. Immunol. 14, 96-102.

Liu, A. Y., Dstoumieux, D., Wong, A. V., Parak, C. H., Valore, E. V., Liu, L., and Ganz, T. (2002). Human $\beta$ defensin-2 production in keratinocytes is regulated by interleukin-1, bacteria, and the state of differentiation. J. Invest. Dermatol. 118, 275-281.

Lourbakos, A., Chinni, C., Thompson, P., Potempa, J., Travis, J., Mackie, E. J., and Pike, R. N. (1998). Cleavage and activation of proteinase-activated receptor-2 on human neutrophils by gingipain- $R$ from Porphyromonas gingivalis. FEBS Lett. 435, 45-48.

Lourbakos, A., Potempa, J., Travis, J., D’Andrea, M. R., Andrade-Gordon, P., Santulli, R., Mackie, E. J., and Pike, R. N. (2001). Arginine-specific protease from Porphyromonas gingivalis activates protease-activated receptors on human oral epithelial cells and induces interleukin-6 secretion. Infect. Immun. 69, 5121-5130.

Mackie, E. J., Pagel, C. N., Smith, R., de Niese, M. R., Song, S. J., and Pike, R. N. (2002). Proteaseactivated receptors: a means of converting extracellular proteolysis into intracellular signals. IUBMB Life. 53, 277-281.

Maisetta, G., Batoni, G., Esin, S., Luperini, F., Pardini, M., Bottai, D., Florio, W., Giuca, M. R., Gabriele, M., and Campa, M. (2003). Activity of human beta-defensin 3 alone or combined with other antimicrobial agents against oral bacteria. Antimicrob. Agents Chemother. 47, 3349-3351.

Mandal, M., and Nagaraj, R. (2002). Antibacterial activities and conformations of synthetic alpha-defensin HNP-1 and analogs with one, two and three disulfide bridges. J. Pept. Res. 59, 95-104.

Marionnet, C., Bernerd, F., Dumas, A., Verrecchia, F., Mollier, K., Compan, D., Bernard, B., Lahfa, M., Leclaire, J., Medaisko, C., et al. (2003). Modulation of gene expression induced in human epidermis by environmental stress in vivo. J. Invest. Dermatol. 121, 1447-1458. 
Mars, W. M., Patmasiriwat, P., Maity, T., Huff, V., Weil, M. M., and Saunders, G. F. (1995). Inheritance of unequal numbers of the genes encoding the human neutrophil defensins HP-1 and HP-3. J. Biol. Chem. 270, 3037130376 .

Mathews, M., Jia, H. P., Guthmiller, J. M., Losh, G., Graham, S., Johnson, G. K., Tack, B. F., and McCray, P. B., Jr. (1999). Production of beta-defensin antimicrobial peptides by the oral mucosa and salivary glands. Infect. Immun. 67, 2740-2745.

McKay, M. S., Olson, E., Hesla, M. A., Panyutich, A., Ganz, T., Perkins, S., and Rossomando, E. F. (1999). Immunomagnetic recovery of human neutrophil defensins from the human gingival crevice. Oral Microbiol. Immunol. 14, 190-193.

McLatchie, L. M., Fraser, N. J., Main, M. J., Wise, A., Brown, J., Thompson, N., Solari, R., Lee, M. G., and Foord, S. M. (1998). RAMPs regulate the transport and ligand specificity of the calcitonin-receptor-like receptor. Nature 393, 333-339.

Medzhitov, R. (2001). Toll-like receptors and innate immunity. Nat. Rev. Immunol. 1, 135-145.

Mineshiba, F., Takashiba, S., Mineshiba, J., Matsuura, K., Kokeguchi, S., and Murayama, Y. (2003). Antibacterial activity of synthetic human B defensin-2 against periodontal bacteria. J. Int. Acad. Periodontol. 5, 3540.

Miyasaki, K. T., and Lehrer, R. I. (1998). Beta-sheet antibiotic peptides as potential dental therapeutics. Int. J. Antimicrob. Agents 9, 269-280.

Mizukawa, N., Sawaki, K., Yamachika, E., Fukunaga, J., Ueno, T., Takagi, S., and Sugahara, T. (2000). Presence of human beta-defensin-2 in oral squamous cell carcinoma. Anticancer Res. 20, 2005-2007.

Mizukawa, N., Sugiyama, K., Ueno, T., Mishima, K., Takagi, S., and Sugahara, T. (1999). Levels of human defensin1 , an antimicrobial peptide, in saliva of patients with oral inflammation. Oral Surg. Oral Med. Oral Pathol. Oral Radiol. Endod. 87, 539-543.

Murakami, M., Ohtake, T., Dorschner, R. A., and Gallo, R. L. (2002). Cathelicidin antimicrobial peptides are expressed in salivary glands and saliva. J. Dent. Res. 81, 845-850.

Nacken, W., Roth, J., Sorg, C., and Kerkhoff, C. (2003). S100A9/S100A8: Myeloid representatives of the S100 protein family as prominent players in innate immunity. Microsc. Res. Tech. 60, 569-580.

Nagaoka, I., Hirota, S., Yomogida, S., Ohwada, A., and Hirata, M. (2000). Synergistic actions of antibacterial neutrophil defensins and cathelicidins. Inflamm. Res. 49, 73-79.

Nieuw Amerongen, A. V., and Veerman, E. C. (2002). Saliva-the defender of the oral cavity. Oral Dis. 8, 1222.

Nikawa, H., Jin, C., Fukushima, H., Makihira, S., and Hamada, T. (2001). Antifungal activity of histatin-5 against non-albicans Candida species. Oral Microbiol. Immunol. 16, 250-252.

Nisapakultorn, K., Ross, K. F., and Herzberg, M. C. (2001). Calprotectin expression in vitro by oral epithelial cells confers resistance to infection by Porphyromonas gingivalis. Infect. Immun. 69, 4242-4247.
Niyonsaba, F., Someya, A., Hirata, M., Ogawa, H., and Nagaoka, I. (2001). Evaluation of the effects of peptide antibiotics human beta-defensins-1/-2 and LL-37 on histamine release and prostaglandin $\mathrm{D}(2)$ production from mast cells. Eur. J. Immunol. 31, 1066-1075.

Nizet, V., Ohtake, T., Lauth, X., Trowbridge, J., Rudisill, J., Dorschner, R. A., Pestonjamasp, V., Piraino, J., Huttner, K., and Gallo, R. L. (2001). Innate antimicrobial peptide protects the skin from invasive bacterial infection. Nature 414, 454-457.

O’Neil, D. A., Porter, E. M., Elewaut, D., Anderson, G. M., Eckmann, L., Ganz, T., and Kagnoff, M. F. (1999). Expression and regulation of the human beta-defensins hBD-1 and hBD-2 in intestinal epithelium. J. Immunol. 163, 6718-6724.

Oppenheim, F. G., Xu, T., McMillian, F. M., Levitz, S. M., Diamond, R. D., Offner, G. D., and Troxler, R. F. (1988). Histatins, a novel family of histidine-rich proteins in human parotid secretion. Isolation, characterization, primary structure, and fungistatic effects on Candida albicans. J. Biol. Chem. 263, 7472-7477.

Page, R. C., Sims, T. J., Geissler, F., Altman, L. C., and Baab, D. A. (1985). Defective neutrophil and monocyte motility in patients with early onset periodontitis. Infect. Immun. 47, 169-175.

Prohaszka, Z., Nemet, K., Csermely, P., Hudecz, F., Mezo, G., and Fust, G. (1997). Defensins purified from human granulocytes bind $\mathrm{C} 1 \mathrm{q}$ and activate the classical complement pathway like the transmembrane glycoprotein gp41 of HIV-1. Mol. Immunol. 34, 809816.

Putsep, K., Carlsson, G., Boman, H. G., and Andersson, M. (2002). Deficiency of antibacterial peptides in patients with morbus Kostmann: an observation study. Lancet 360, 1144-1149.

Quinones-Mateu, M. E., Lederman, M. M., Feng, Z., Chakraborty, B., Weber, J., Rangel, H. R., Marotta, M. L., Mirza, M., Jiang, B., Kiser, P., et al. (2003). Human epithelial beta-defensins 2 and 3 inhibit HIV-1 replication. Aids 17, F39-48.

Raj, P. A., Edgerton, M., and Levine, M. J. (1990). Salivary histatin 5: dependence of sequence, chain length, and helical conformation for candidacidal activity. J. Biol. Chem. 265, 3898-3905.

Ross, K. F., and Herzberg, M. C. (2001). Calprotectin expression by gingival epithelial cells. Infect. Immun. 69, 3248-3254.

Russell, J. P., Diamond, G., Tarver, A. P., Scanlin, T. F., and Bevins, C. L. (1996). Coordinate induction of two antibiotic genes in tracheal epithelial cells exposed to the inflammatory mediators lipopolysaccharide and tumor necrosis factor-a. Infect. Immun. 64, 1565-1568.

Sahasrabudhe, K. S., Kimball, J. R., Morton, T., Weinberg, A., and Dale, B. A. (2000). Expression of the antimicrobial peptide, human b-defensin 1 , in duct cells of minor salivary glands and detection in saliva. J. Dent. Res. 79, 1669-1674

Saito, T., Ishihara, K., Kato, T., and Okuda, K. (1997). Cloning, expression, and sequencing of a protease gene from Bacteroides forsythus ATCC 43037 in Escherichia coli. Infect. Immun. 65, 4888-4891. 
Schonwetter, B. S., Stolzenberg, E. D., and Zasloff, M. A. (1995). Epithelial antibiotics induced at sites of inflammation. Science 267, 1645-1648.

Schroder, J. M., and Harder, J. (1999). Human betadefensin-2. Int J. Biochem. Cell Biol. 31, 645-651.

Schroeder, H. E., and Listgarten, M. A. (1997). The gingival tissues: the architecture of periodontal protection. Periodontology 2000. 13, 91-120.

Schutte, B. C., Mitros, J. P., Bartlett, J. A., Walters, J. D., Jia, H. P., Welsh, M. J., Casavant, T. L., and McCray, P. B., Jr. (2002). Discovery of five conserved beta defensin gene clusters using a computational search strategy. Proc. Natl. Acad. Sci. USA 99, 2129-2133.

Scott, M. G., Davidson, D. J., Gold, M. R., Bowdish, D., and Hancock, R. E. (2002). The human antimicrobial peptide LL-37 is a multifunctional modulator of innate immune responses. J. Immunol. 169, 3883-3891.

Scott, M. G., Rosenberger, C. M., Gold, M. R., Finlay, B. B., and Hancock, R. E. (2000). An alpha-helical cationic antimicrobial peptide selectively modulates macrophage responses to lipopolysaccharide and directly alters macrophage gene expression. J. Immunol. 165, 33583365.

Singh, P. K., Jia, H. P., Wiles, K., Hesselberth, J., Liu, L., Conway, B. A., Greenberg, E. P., Valore, E. V., Welsh, M. J., Ganz, T., et al. (1998). Production of beta-defensins by human airway epithelia [published erratum appears in Proc. Natl. Acad. Sci. USA 1999 Mar 2;96(5):2569]. Proc. Natl. Acad. Sci. USA 95, 14961-14966.

Situ, H., and Bobek, L. A. (2000). In vitro assessment of antifungal therapeutic potential of salivary histatin-5, two variants of histatin-5, and salivary mucin (MUC7) domain 1. Antimicrob. Agents Chemother. 44, 14851493.

Socransky, S. S., Haffajee, A. D., Cugini, M. A., Smith, C., and Kent, R. L., Jr. (1998). Microbial complexes in subgingival plaque. J. Clin. Periodontol. 25, 134-144.

Starner, T. D., Barker, C. K., Jia, H. P., Kang, Y., and McCray, P. B., Jr. (2003). CCL20 is an inducible product of human airway epithelia with innate immune properties. Am. J. Respir. Cell Mol. Biol. 29, 627-633.

Stolzenberg, E. D., Anderson, G. M., Ackermann, M. R., Whitlock, R. H., and Zasloff, M. (1997). Epithelial antibiotic induced in states of disease. Proc. Natl. Acad. Sci. USA 94, 8686-8690.

Tanaka, D., Miyasaki, K. T., and Lehrer, R. I. (2000). Sensitivity of Actinobacillus actinomycetemcomitans and Capnocytophaga spp. to the bactericidal action of LL-37: a cathelicidin found in human leukocytes and epithelium. Oral Microbiol. Immunol. 15, 226-231.

Tonetti, M. S. (1997). Molecular factors associated with compartmentalization of gingival immune responses and transepithelial neutrophil migration. J. Periodontal Res. 32, 104-109.

Tonetti, M. S., Imboden, M. A., and Lang, N. P. (1998). Neutrophil migration into the gingival sulcus is associated with transepithelial gradients of interleukin8 and ICAM-1. J. Periodontol. 69, 1139-1147.

Toomes, C., James, J., Wood, A. J., Wu, C. L., McCormick, D., Lench, N., Hewitt, C., Moynihan, L., Roberts, E., Woods, C. G., et al. (1999). Loss-of-function mutations in the cathepsin $\mathrm{C}$ gene result in periodontal disease and palmoplantar keratosis. Nat. Genet. 23, 421-424.

Tsai, H., and Bobek, L. A. (1998). Human salivary histatins: promising anti-fungal therapeutic agents. Crit. Rev. Oral Biol. Med. 9, 480-497.

Turner, J., Cho, Y., Dinh, N. N., Waring, A. J., and Lehrer, R. I. (1998). Activities of LL-37, a cathelin-associated antimicrobial peptide of human neutrophils. Antimicrob. Agents Chemother. 42, 2206-2214.

Uehara, A., Sugawara, S., Muramoto, K., and Takada, H. (2002a). Activation of human oral epithelial cells by neutrophil proteinase 3 through protease-activated receptor-2. J. Immunol. 169, 4594-4603.

Uehara, A., Sugawara, S., and Takada, H. (2002b). Priming of human oral epithelial cells by interferon-gamma to secrete cytokines in response to lipopolysaccharides, lipoteichoic acids and peptidoglycans. J. Med. Microbiol. $51,626-634$.

Ueta, E., Tanida, T., Doi, S., and Osaki, T. (2000). Regulation of Candida albicans growth and adhesion by saliva. J. Lab. Clin. Med. 136, 66-73.

Valore, E. V., Park, C. H., Quayle, A. J., Wiles, K. R., McCray, P. B., Jr., and Ganz, T. (1998). Human betadefensin-1: an antimicrobial peptide of urogenital tissues. J. Clin. Invest. 101, 1633-1642.

van den Berg, R. H., Faber-Krol, M. C., van Wetering, S., Hiemstra, P. S., and Daha, M. R. (1998). Inhibition of activation of the classical pathway of complement by human neutrophil defensins. Blood 92, 3898-3903.

vanderSpek, J. C., Wyandt, H. E., Skare, J. C., Milunsky, A., Oppenheim, F. G., and Troxler, R. F. (1989). Localization of the genes for histatins to human chromosome $4 q 13$ and tissue distribution of the mRNAs. Am. J. Hum. Genet. 45, 381-387.

van'tHof, W., Reijnders, I. M., Helmerhorst, E. J., WalgreenWeterings, E., Simoons-Smit, I. M., Veerman, E. C., and Amerongen, A. V. (2000). Synergistic effects of low doses of histatin 5 and its analogues on amphotericin B anti-mycotic activity. Antonie Van Leeuwenhoek. 78, 163-169.

Vatta, S., Boniotto, M., Bevilacqua, E., Belgrano, A., Pirulli, D., Crovella, S., and Amoroso, A. (2000). Human beta defensin 1 gene: six new variants. Hum. Mutat. 15, 582-583.

Weinberg, A., Krisanaprakornkit, S., and Dale, B. A. (1998). Epithelial antimicrobial peptides: review and significance for oral applications. Crit. Rev. Oral Biol. Med. 9, 399-414.

Wilson, C. L., Ouellette, A. J., Satchell, D. P., Ayabe, T., Lopez-Boado, Y. S., Stratman, J. L., Hultgren, S. J., Matrisian, L. M., and Parks, W. C. (1999). Regulation of intestinal alpha-defensin activation by the metalloproteinase matrilysin in innate host defense. Science 286, 113-117.

Wu, Z., Hoover, D. M., Yang, D., Boulegue, C., Santamaria, F., Oppenheim, J. J., Lubkowski, J., and Lu, W. (2003). Engineering disulfide bridges to dissect antimicrobial and chemotactic activities of human beta-defensin 3 . Proc. Natl. Acad. Sci. USA 100, 8880-8885.

Yang, D., Biragyn, A., Kwak, L. W., and Oppenheim, J. J. (2002). Mammalian defensins in immunity: more than just microbicidal. Trends Immunol. 23, 291-296. 
Yang, D., Chen, Q., Chertov, O., and Oppenheim, J. J. (2000). Human neutrophil defensins selectively chemoattract naive $\mathrm{T}$ and immature dendritic cells. J. Leukoc. Biol. 68, 9-14.

Yang, D., Chertov, O., Bykovskaia, S. N., Chen, Q., Buffo, M. J., Shogan, J., Anderson, M., Schroder, J. M., Wang, J. M., Howard, O. M., and Oppenheim, J. J. (1999). Beta-defensins: linking innate and adaptive immunity through dendritic and T cell CCR6. Science 286, 525-528.
Zanetti, M., Gennaro, R., Scocchi, M., and Skerlavaj, B. (2000). Structure and biology of cathelicidins. Adv. Exp. Med. Biol. 479, 203-218.

Zhang, L., Yu, W., He, T., Yu, J., Caffrey, R. E., Dalmasso, E. A., Fu, S., Pham, T., Mei, J., Ho, J. J., et al. (2002). Contribution of human alpha-defensin 1, 2, and 3 to the anti-HIV-1 activity of CD8 antiviral factor. Science 298, 995-1000.

Zhao, C., Wang, I., and Lehrer, R. I. (1996). Widespread expression of beta-defensin hBD-1 in human secretory glands and epithelial cells. FEBS Lett. 396, 319-322. 


\section{Further Reading}

Caister Academic Press is a leading academic publisher of advanced texts in microbiology, molecular biology and medical research. Full details of all our publications at caister.com

- MALDI-TOF Mass Spectrometry in Microbiology Edited by: M Kostrzewa, S Schubert (2016) www.caister.com/malditof

- Aspergillus and Penicillium in the Post-genomic Era Edited by: RP Vries, IB Gelber, MR Andersen (2016) www.caister.com/aspergillus2

- The Bacteriocins: Current Knowledge and Future Prospects Edited by: RL Dorit, SM Roy, MA Riley (2016)

www.caister.com/bacteriocins

- Omics in Plant Disease Resistance Edited by: V Bhadauria (2016) www.caister.com/opd

- Acidophiles: Life in Extremely Acidic Environments Edited by: R Quatrini, DB Johnson (2016) www.caister.com/acidophiles

- Climate Change and Microbial Ecology: Current Research and Future Trend

Edited by: J Marxsen (2016)

www.caister.com/climate

- Biofilms in Bioremediation: Current Research and Emerging Technologies

Edited by: G Lear (2016)

www.caister.com/biorem

- Microalgae: Current Research and Applications Edited by: MN Tsaloglou (2016) www.caister.com/microalgae

- Gas Plasma Sterilization in Microbiology: Theory, Applications, Pitfalls and New Perspectives Edited by: H Shintani, A Sakudo (2016) www.caister.com/gasplasma

- Virus Evolution: Current Research and Future Directions Edited by: SC Weaver, M Denison, M Roossinck, et al. (2016) www.caister.com/virusevol

- Arboviruses: Molecular Biology, Evolution and Control Edited by: N Vasilakis, DJ Gubler (2016) www.caister.com/arbo

- Shigella: Molecular and Cellular Biology Edited by: WD Picking, WL Picking (2016) www.caister.com/shigella

-Aquatic Biofilms: Ecology, Water Quality and Wastewater Treatment

Edited by: AM Romaní, H Guasch, MD Balaguer (2016)

www.caister.com/aquaticbiofilms

- Alphaviruses: Current Biology

Edited by: S Mahalingam, L Herrero, B Herring (2016)

www.caister.com/alpha

- Thermophilic Microorganisms

Edited by: F Li (2015)

www.caister.com/thermophile
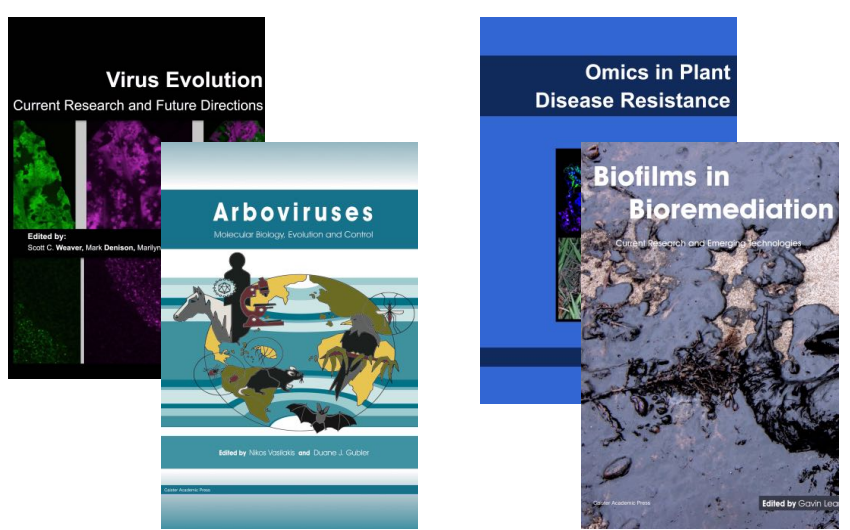
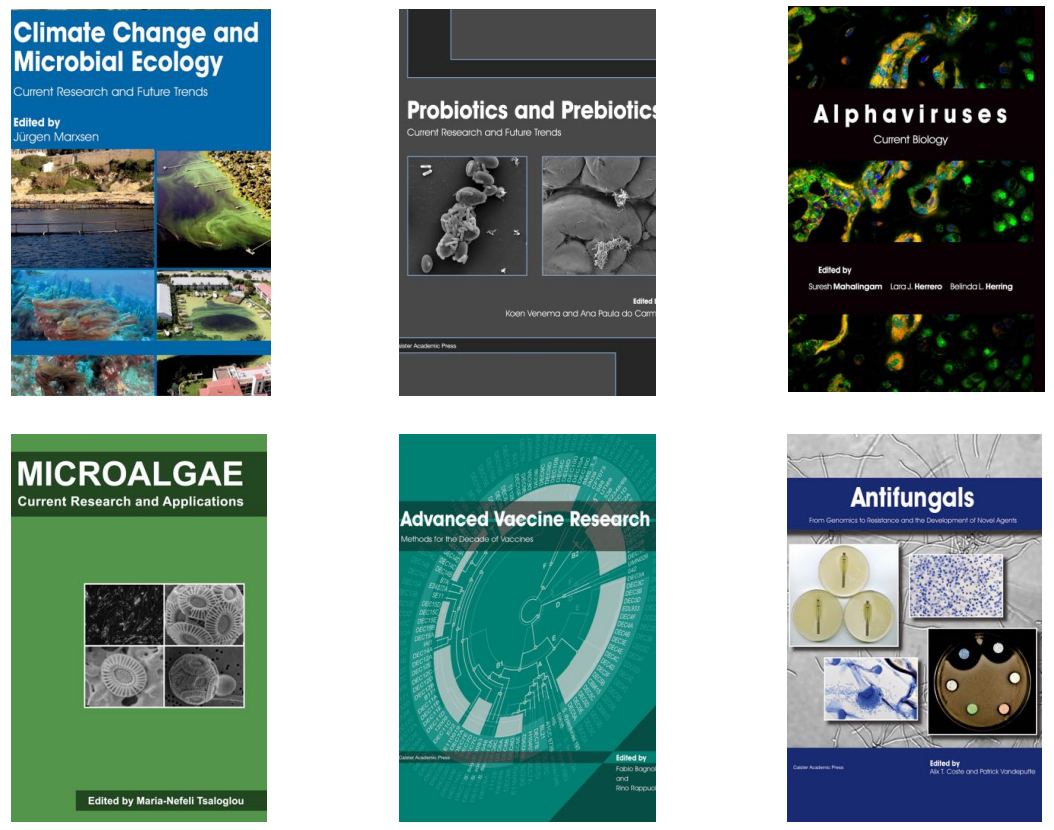

- Flow Cytometry in Microbiology: Technology and Applications Edited by: MG Wilkinson (2015) www.caister.com/flow

- Probiotics and Prebiotics: Current Research and Future Trends Edited by: K Venema, AP Carmo (2015) www.caister.com/probiotics

- Epigenetics: Current Research and Emerging Trends Edited by: BP Chadwick (2015) www.caister.com/epigenetics2015

- Corynebacterium glutamicum: From Systems Biology to Biotechnological Applications

Edited by: A Burkovski (2015)

www.caister.com/cory2

- Advanced Vaccine Research Methods for the Decade of Vaccines

Edited by: F Bagnoli, R Rappuoli (2015)

www.caister.com/vaccines

- Antifungals: From Genomics to Resistance and the Development of Novel Agents

Edited by: AT Coste, P Vandeputte (2015)

www.caister.com/antifungals

- Bacteria-Plant Interactions: Advanced Research and Future Trends Edited by: J Murillo, BA Vinatzer, RW Jackson, et al. (2015) www.caister.com/bacteria-plant

\section{- Aeromonas}

Edited by: J Graf (2015)

www.caister.com/aeromonas

- Antibiotics: Current Innovations and Future Trends

Edited by: S Sánchez, AL Demain (2015)

www.caister.com/antibiotics

- Leishmania: Current Biology and Contro Edited by: S Adak, R Datta (2015) www.caister.com/leish2

- Acanthamoeba: Biology and Pathogenesis (2nd edition) Author: NA Khan (2015)

www.caister.com/acanthamoeba2

- Microarrays: Current Technology, Innovations and Applications Edited by: Z He (2014)

www.caister.com/microarrays2

- Metagenomics of the Microbial Nitrogen Cycle: Theory, Methods and Applications

Edited by: D Marco (2014)

www.caister.com/n2 